\title{
RESPONSE OF PHYSIOLOGY, GROWTH AND YIELD OF SOYBEAN VARIETIES ON FERTILIZATION TREATMENT IN AGROFORESTRY SYSTEMS
}

\author{
Rizwan Muhmammad ${ }^{1 *}$, Rauf Abdul $^{2}$, Rahmawaty ${ }^{3}$, Akub Erwin Nyak ${ }^{2}$ \\ ${ }^{1}$ Doctoral Program of Agricultural Sciences, Faculty of Agriculture, \\ Universitas Sumatera Utara, Indonesia \\ ${ }^{2}$ Study Program of Agrotechnology, Faculty of Agriculture, \\ Universitas Sumatera Utara, Indonesia \\ ${ }^{3}$ Faculty of Forestry, Universitas Sumatera Utara, Indonesia \\ *E-mail: muhammadrizwanagr@gmail.com
}

\begin{abstract}
In agroforestry system, magnitude of crops adaptive responses to shade depends on amount of shade. Hence, soybean may modify its growth to adapt to competition in agroforestry systems. The objective of this study was to describe the growth and yield of soybean varietes grown in intercropping under Mindi (Melia azedarach) with several doses of fertilization. This research has been conducted in Kwala Bekala Arboretum, Universitas Sumatera Utara using factorial design, consisting of soybean varieties $(V)$ and fertilizing dosage $(P)$. Variety factors are consisted of Anjasmoro; Burangrang, Dena-1, and Dena-2. Fertilization factor consisted of $50 \%$ of recommended dosage (urea $50 \mathrm{~kg} / \mathrm{ha}, S P-36100 \mathrm{~kg} / \mathrm{ha}, \mathrm{KCl} 50 \mathrm{~kg} / \mathrm{ha}$ ), recommended dose (urea $100 \mathrm{~kg} / \mathrm{ha}, S P-36200 \mathrm{~kg} / \mathrm{ha}, \mathrm{KCl} 100 \mathrm{~kg} / \mathrm{ha}$ ); and $150 \%$ of recommended dosage (urea $150 \mathrm{~kg} / \mathrm{ha}, \mathrm{SP}-36300 \mathrm{~kg} / \mathrm{ha}, \mathrm{KCl} 150 \mathrm{~kg} / \mathrm{ha}$ ). The difference in growth response is closely related to environmental conditions such as light intensity, temperature and humidity levels received, that affects the plant height parameters, leaf chlorophyll, flowering age and yield components. In addition to shade, fertilization also has a significant effect, where under shaded conditions, to produce optimal growth, a dosage of $150 \%$ of the recommendations is required, with soybean Dena- 2 variety the most adaptive variety.
\end{abstract}

\section{KEY WORDS}

Soybean, shading, Mindi (Melia azedarach).

Soybean is an oil seed plant in the world that provides $58 \%$ of total oil seed production (Board, 2013), also being one of the main protein (Matsuo et al. 2016). Soybean is the main commodity in Indonesia that contributes to food security, but its availability is often constrained. In 2016, soybean production in North Sumatera was $5062 \mathrm{~kg}$ with a harvest area of $3955 \mathrm{ha}$, equivalent to a productivity of $1.28 \mathrm{t} / \mathrm{ha}$. The planting and harvesting area of soybean in North Sumatra has continued to decline since 2009, where the planting area has been reduced from 11413 ha to 3955 ha. Such decrease is due to high conversion rate of agricultural land to non-agricultural land. Thus, the existence of forests to ensure soybean production is very necessary, one of which is by intercropping with Melia azedarach. The tree is a multipurpose tree species that is rapidly growing because all parts of the plant can be utilized. Wijayanto et.al (2016) explain that Melia azedarach have a tree canopy cone with a balanced architecture, so the potential is developed with agroforestry. Planting trees together with crops in one area have a positive impact one of which provides a source of organic matter. The leaves of the plant Melia azedarach can be a source of nutrients for crop soybean underneath.

Agroforestry systems are feasible to be developed to achieve the goals of land use optimization, because they consist of integrated cultivation between agricultural and forest species (Caron et al. 2018). In addition, this system is used for the purpose of maximizing sustainable agricultural production systems, as well as accelerating the recovery, physical, chemical and biological properties of soils (Tracy and Zhang 2008, Salton et al. 2013). 
Agroforestry systems have some advantages, among other yield obtained from two crops, namely agricultural and forestry crops. Intercropping of Melia azedarach with soybean is expected to be the right combination due to their respective advantages. The interaction between these crops is expected to increase the productivity of the two agroforestry components.

The growth of soybean under forest trees stands in agroforestry system is a series of processes, ranging from solar radiation to plant leaves, photosynthesis, carbohydrate partitioning, respiration, evapotranspiration, and their interactions with plants development stage, shade and agro-climate. Photosynthesis process on shading stress is reactions processes that require light. The study of crop agronomy in intercropping systems is still needed because the design of intercropping systems has traditionally focused on the selection and management of tree species, with little attention paid to the flexibility of plant components (Manceur et al, 2008). In Indonesia, many related studies have been carried out, but still on a laboratory scale (Jufri, 2006; Wirnas, 2007; Kisman, 2007; La Muhuria, 2006; Qadir, 2012), and similar research on a field scale is still limited (Hartoyo, 2014).

Trees and crops compete for growth factor, for light, nutrient and water. In general, soybean will adapt to a reduction in photosynthesis activity by reducing yield, growth rate, rate of grain filling, and leaf thickness (Egli et al. 1980; Heindl and Brun 1983; Peet and Kramer 1980). Shade tends to increase abscission of pods and flowers, height, leaf area, petiole length, and partition of dry matter to leaves (Begonia et al. 1988; Burkey et al. 1997; Trang and Giddens 1980; Wahua and Miller 1978). The magnitude of these adaptive responses to shade depends on the amount of shade. Hence, soybean may modify its growth to adapt to competition in agroforestry systems. The objective of this study was to describe the growth and yield of soybean varieties grown in intercropping under Mindi (Melia azedarach) tree with several doses of fertilization.

\section{METHODS OF RESEARCH}

This research has been conducted in Kwala Bekala Arboretum, Universitas Sumatera Utara, using 2 factorial design, consisting of soybean varieties $(\mathrm{V})$ and fertilizing dosage $(\mathrm{P})$. Variety factors are consisted of 4 levels namely $\mathrm{V} 1=$ Anjasmoro; V2 = Burangrang, $\mathrm{V} 3=$ Dena-1, V4 = Dena-2. Fertilization factor consisted of 3 levels, namely: $\mathrm{P} 1=50 \%$ of recommended dosage (urea $50 \mathrm{~kg} / \mathrm{ha}, \mathrm{SP}-36100 \mathrm{~kg} / \mathrm{ha}, \mathrm{KCl} 50 \mathrm{~kg} / \mathrm{ha}$ ), P2 = recommended dose (urea $100 \mathrm{~kg} / \mathrm{ha}, \mathrm{SP}-36200 \mathrm{~kg} / \mathrm{ha}, \mathrm{KCl} 100 \mathrm{~kg} / \mathrm{ha}$ ); and P3 = 150\% of recommended dosage (urea $150 \mathrm{~kg} / \mathrm{ha}$, SP-36 $300 \mathrm{~kg} / \mathrm{ha}, \mathrm{KCl} 150 \mathrm{~kg} / \mathrm{ha}$ ).

Each experiment unit has been repeated 3 times; thus, the total number of experimental units is 36 . The collected data were analyzed using analysis of variance and then means difference test was performed by least significant difference test (LSD) at $5 \%$.

Observations made include growth phase and yield. Observation on vegetative phase was carried out by observing plant growth in each experimental unit. Observations on yield were carried out on 10 samples in each experimental unit. The observed variables are as follows:

- Plant height: observed at 3, 6 and 9 days after planting (DAP) to flowering;

- Leaves Chlorophyll;

- Flowering Age (days), the first flower formation is observed;

- Number of filled and empty pods is calculated for each plant;

- Number of Seeds: total number of pods is calculated both for filled and empty pods;

- Weight of 100 Seeds s (gr), weighed with analytical scales;

- Weight of Seeds per plot (gr), weighed with analytical scales.

\section{RESULTS AND DISCUSSION}

Plant Height and Flowering Age. Interaction of varieties and fertilizing doses have a significant effect on at all observations, 21 DAP, 42 DAP, and 63 DAP (Figure 1 a-c). 
The difference of plant height between varieties is varies every week. As soybean ages, the difference in plant height is larger for each variety.

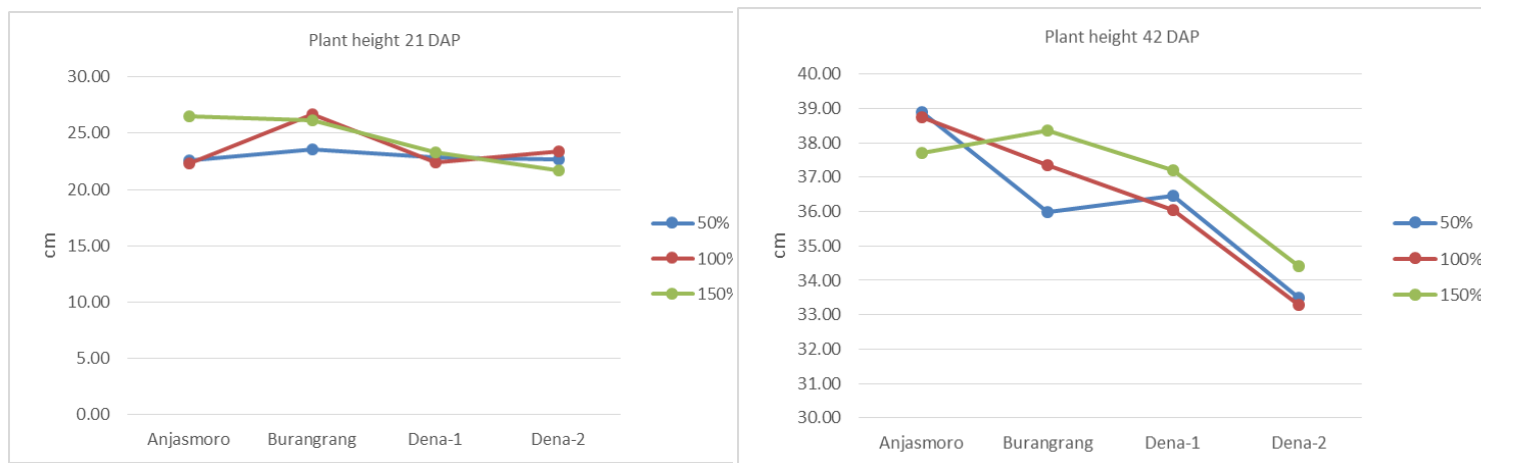

Figure 1a - Plant height at 21 DAP

Figure $1 \mathrm{~b}-$ Plant height at $42 \mathrm{DAP}$
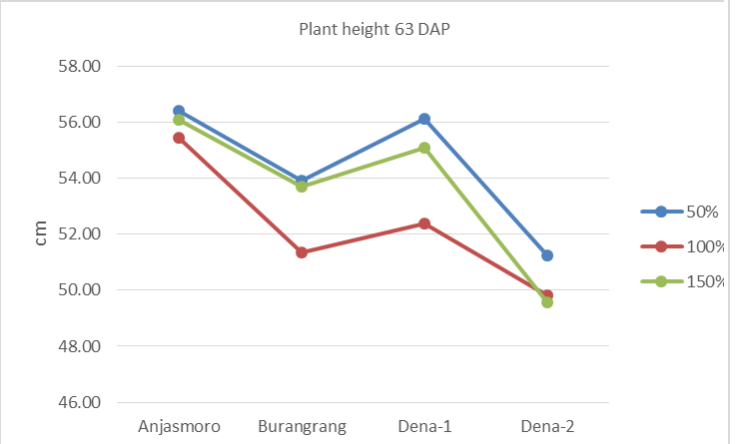

Figure 1c-Plant height at 63 DAP

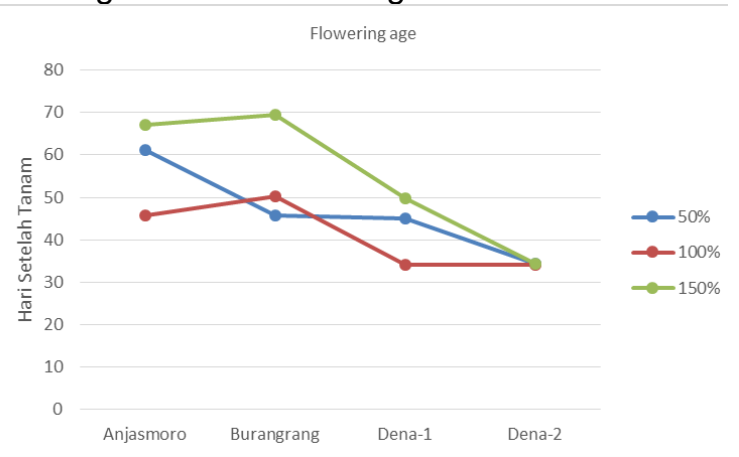

Figure 1d - Flowering Age

Dena-1 variety has the lowest height, while Anjasmoro variety is the highest. At 21 days after planting, Burangrang variety with a fertilizer dose of $100 \%$ has the highest height, followed by Anjasmoro at a dose of $150 \%$. The lowest height was found in Dena-2 at a dose of $150 \%$. At 9 weeks after planting, plant height of Anjasmoro, Burangrang, Dena-1, and Dena-2 were $56.06 \mathrm{~cm}, 53.38 \mathrm{~cm}, 46.61 \mathrm{~cm}$ and $47.19 \mathrm{~cm}$. According to description of plant height of Anjasmoro, Burangrang, Dena-1, and Dena-2 varieties are $\pm 64-68 \mathrm{~cm}, \pm 60-70 \mathrm{~cm}$, $\pm 59 \mathrm{~cm}$, and \pm 40 respectively. The finding of this study approached to the high description of each variety, even Dena-2 is slightly higher than the description. This shows that this variety has an adaptation mechanism to shaded conditions through increased plant height. Caron et.al (2018) states that the reduced light received by plants will reduce root growth, and plants show etiolation symptoms by showing increased stem length at low light intensity. The increase in stem height is related to plant adaptation process to increase light penetration into plant canopies. Querne et al. (2017) also reported that the increase in plant height varies between genotypes in a shaded environment, but generally tolerant genotypes have a greater ability to increase plant height than sensitive genotypes.

All fertilizing doses have a significant effect on the flowering age of soybean varieties (figure 1d). Dena-2 is known as the fastest and simultaneously flowering variety at each fertilization level, namely 34 days after planting. On the other hand, Anjasmoro variety produces the longest flower at 61 DAP, 46 DAP and 67 DAP at each fertilization level. The shading triggers morphological and anatomic changes such as stimulating hypocotyl growth and petiole lengths, decreasing and developing leaves, branching acceleration, flowering acceleration and reduction of reserve resources for storage and reproduction. As a result, soybeans under shading become older. Karamoy, (2009) stated that soybean plants grown in low light conditions generally have a faster flowering age. Flowering process can be formed due to the presence of soluble proteins (phytochromes). High light intensity converts pigments into forms that initiate flowering induction.

According to variety description, Dena-2 is the genotype that is most close to the normal flowering age, namely 35 days after planting. The flowering of soybean is strongly 
influenced by varieties, length of day or length of irradiation, temperature and Dena varieties are classified as deterministic growth types such as simultaneous flowering.

Leaves Chlorophyll. Interaction of varieties and fertilizing doses has no significant effect on leaf tip, middle and base chlorophyll parameters, but has significant effect on total chlorophyll. The most active chlorophyll is indicated by the chlorophyll content in each location, namely the tip, middle and base. In leaf base (figure 2a), Dena-1 variety and $100 \%$ of recommended dosage produce the highest chlorophyll content. Dena-1 variety also produces the highest leaf chlorophyll at $150 \%$ of recommended dose (figure 1b). Likewise, Dena-1 variety also has the highest levels at the tip and total chlorophyll (figures $2 \mathrm{c}, \mathrm{d}$ ).

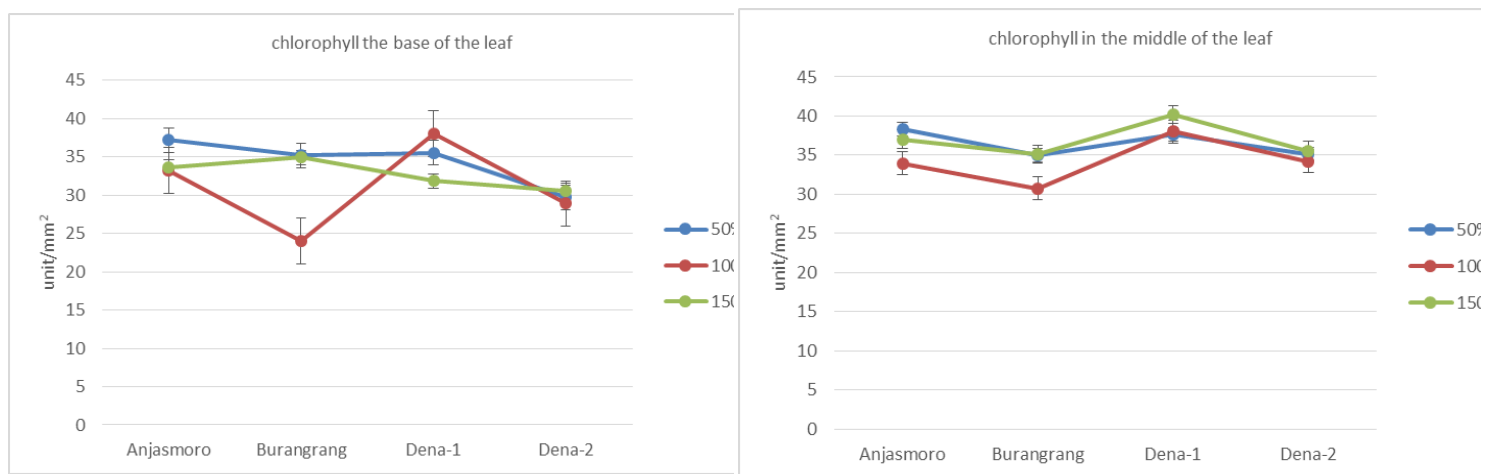

Figure $2 \mathrm{a}-$ Chlorophyll at the base of leaf

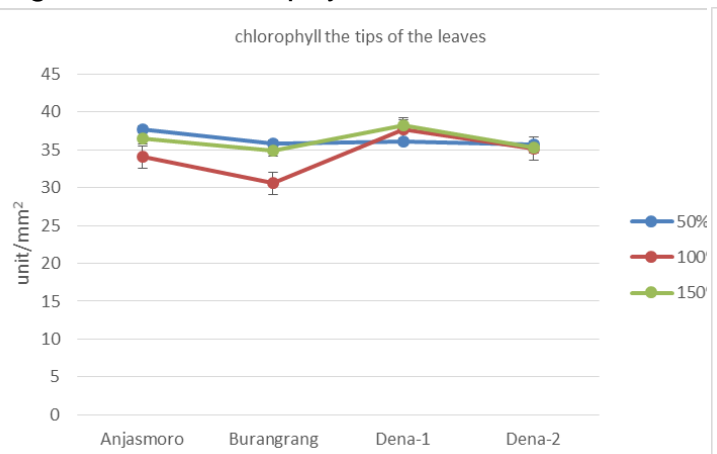

Figure $2 \mathrm{c}-$ Chlorophyll at the tips of leaf
Figure $2 b-C h l o r o p h y l l$ at the middle of leaf

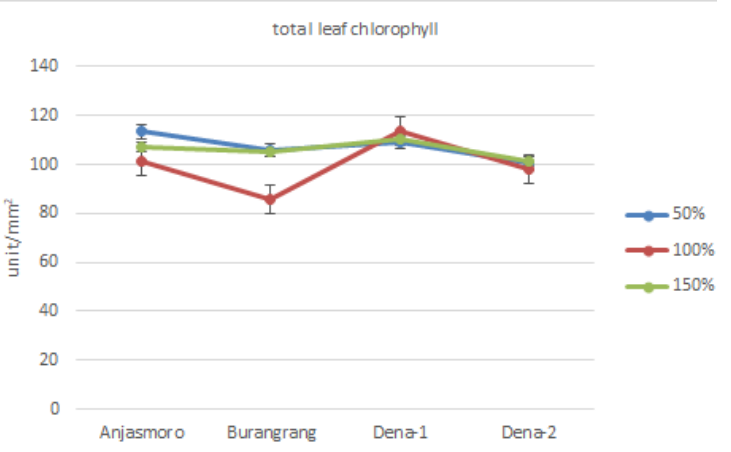

Figure $2 \mathrm{~d}-$ Total of Leaf chlorophyll

The higher chlorophyll increases in Dena variety compared to other varieties shows that this variety is more effective in capturing limited light in a shaded environment, especially at the edges. The higher levels of Chlorophyll under shaded conditions, allows for optimal growth and production potential, because $50 \%$ of the light energy can be transferred to the reaction center through plant chlorophyll (Croce et al. 2001). This is confirmed by Djukri \& Purwoko, (2003); Chairudin et.al, (2015) that leaves formed under low light intensity conditions show an increase in the amount of chlorophyll and contain four to five more times chlorophyll $a$ and $b$ per unit volume of chloroplast and has a lower chlorophyll $a / b$ ratio, reduced non-chloroplast pigments content such as anthocyanins than in full light. This ia because in full light, it has an increased light harvesting complex thereby increasing the efficiency of light capture for photosynthesis.

At high light intensity, the presence of photons is abundance, thus affecting leaves ability to process light. In full light conditions, the ability of leaves to process light must be greater than in low light conditions, consequently the optimization of leaf function is more for harvesting light than processing energy.

Number of filled and empty pods. Interaction of varieties and fertilizing doses has a significant effect on the number of filled pods. Dena-1 variety with fertilization dosage 1.5 times of recommendation has the highest number of filled pods, namely 31.9 pods/plant, while Dena-1 variety at the recommended dosage has the lowest number of filled pods, namely 10.5 pods/plant. But from the efficiency of resource utilization, at a dose of 0.5 recommendations, anjasmoro and Dena-2 produce a higher number of filled pods than 2 
other varieties (Dena-1 and Burangrang), which are 24.1 pods/ plant and 20.5 pods/plants (figure 3a-b).

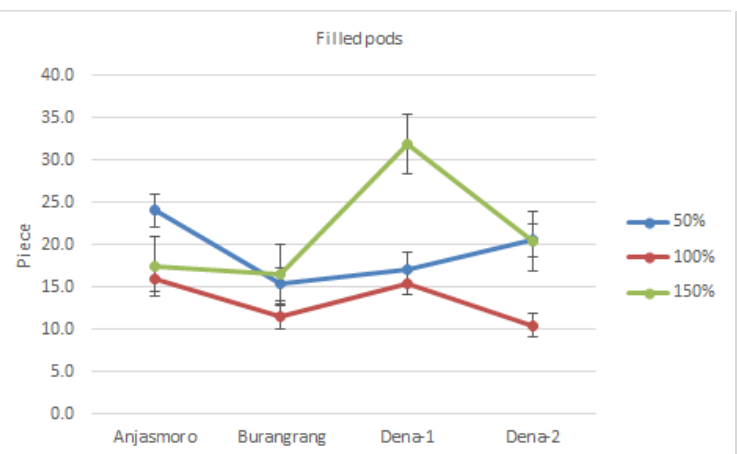

Figure $3 a-$ Number of filled pods

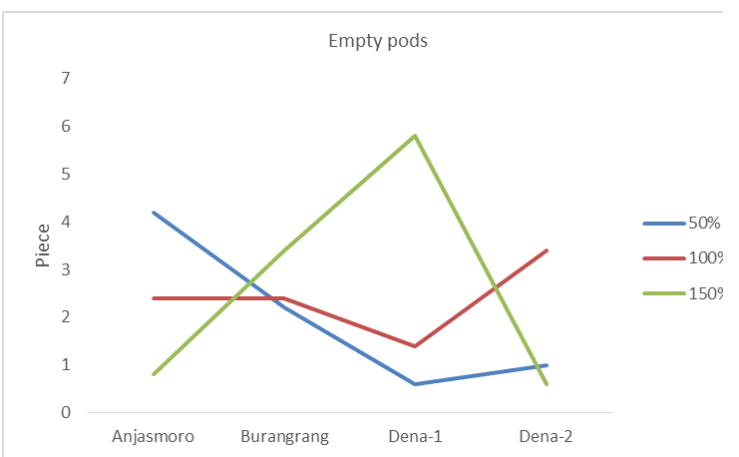

Figure $3 b-$ Number of empty pods

For the parameter of empty pods, Dena- 1 variety at a dose of 1.5 recommendations has the emptiest pods, ie 5.8 pods/plants, but at a dose of 0.5 recommendations, this variety also produces the lowest empty pods, ie 0.6 pods/plants. At a dose of 1.5 recommendation, the lowest empty pods were found in Dena-2 variety, namely 0.6 pods/plants. Such condition is related to adaptability and response of each variety to fertilization and the environment, especially humidity. Optimal air humidity for soybean ranges from $75-90 \%$ during the plant grows period to pod filling phase. The humidity in the Mindi stands reaches $80 \%$, this condition affected to soil moisture. Similar statement is related to the one of the present study, Reynolds et al. (2007) and Viswanath et al. (2014) also found that soil moisture was significantly correlated with soybean yield component, including pod.

Number of seeds, Weight of 100 Seeds and Weight per plot. Parameter of the weight of 100 seeds is significantly affected by the presence of shade on soybean, variety of Anjasmoro have the highest weight of 100 seeds, followed by Dena-2 at $50 \%$ recommended dose of fertilizer. The lowest weight of 100 seeds is found on Dena-2 at $100 \%$ dose recommendation of fertilizer.

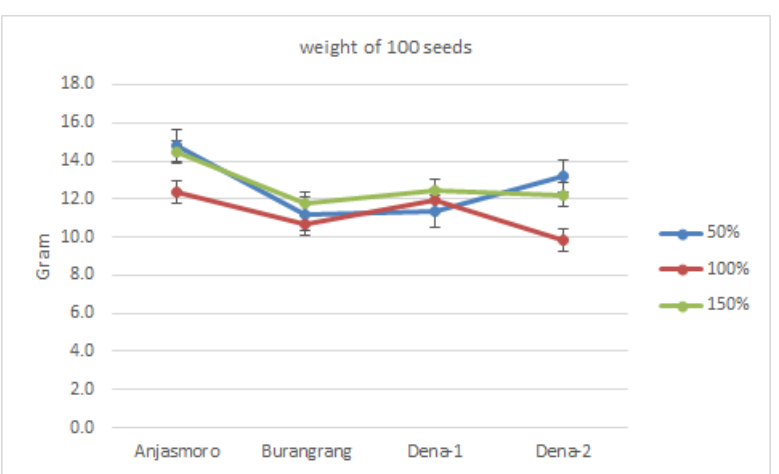

Figure $4 a-$ Weight of 100 seeds

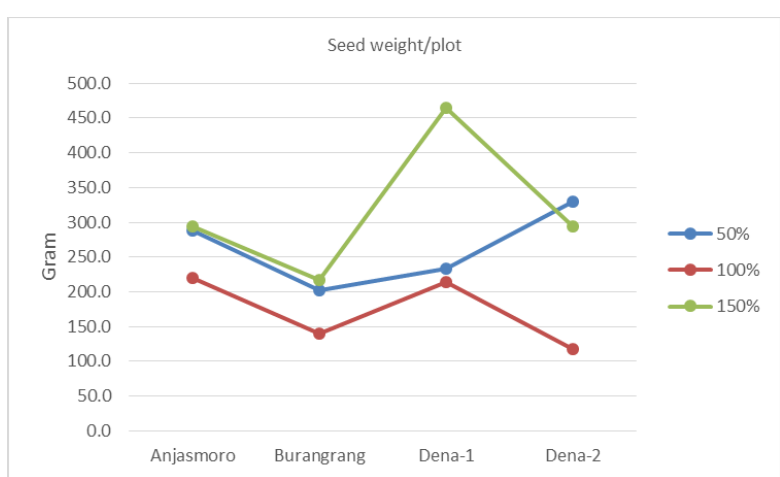

Figure $4 b-$ Seed weight of 100 seeds/plot

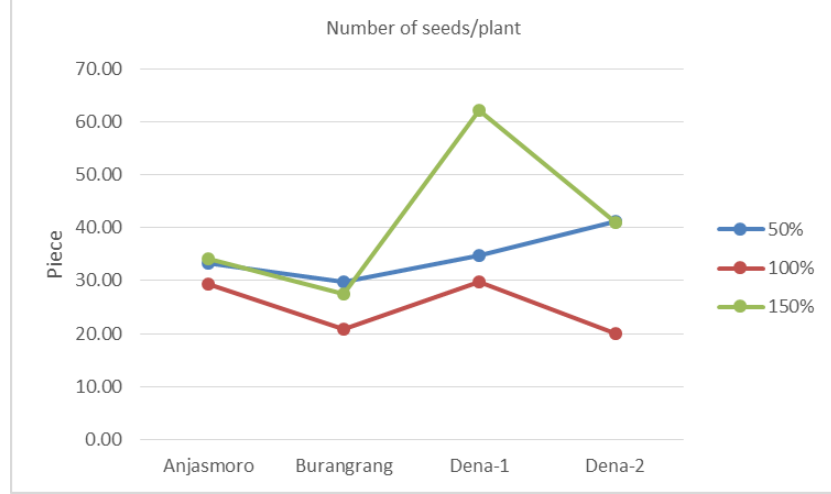

Figure 4c-Number of Seeds/plant 
Weight of 100 seeds is a character to determine the size of soybean seeds, the greater the weight of 100 seeds, the bigger size of soybean seeds. Soybean that grow in a shaded environment at generative phase will experience a decrease in photosynthetic activity which in turn reduce allocation of photosynthate to the reproductive organs (Kakiuchi \& Kobata 2004). This causes the seed size to be smaller than in open conditions. This is evident from the shade treatment gives a significant effect on the weight of 100 soybean seeds. Seed weight parameters per plot which showed the highest production potential per unit land area were found in Mindi shade, namely 251.15 grams, while the lowest weight is in rubber shade, namely $47.48 \mathrm{gr}$. These finding is in line with other production parameters under Mindi shade. In other words, Mindi shade providing the most optimal growing environment for soybean growth and production in an agroforestry system.

The weights of 100 seeds of the four tested varieties were in the range of $10 \mathrm{gr}$, whereas in the high description, Dena-1, Dena-2, Anjasmoro, and Burangrang have the weights of 100 seeds, is $\pm 14.3 \mathrm{gr}, 13 \mathrm{gr}, 14.8-15.3 \mathrm{gr}$, and $\pm 17 \mathrm{~g}$, respectively (Balitkabi 2012). The results of this study are lower than the range of the description.

These finding indicate that at low light intensity due to shading, seeds formation and filling of Dena-1 and Anjasmoro are better than the two other varieties. This condition is due to the higher photosynthetic rate of tolerant varieties so that the need for assimilates such as sucrose, fructose and glucose for seed formation and filling can be fulfilled. Richards (2000) explains that the high rate of photosynthesis is a plant's response to the increased demand for assimilation which is controlled by a large number of seeds. Muhuria (2007) also stated that in the seed filling phase, the need for assimilation would increase, which was marked by an increase in SPS (Sucrose phosphate synthase), one of the enzymes which responsible for sucrose synthesis. Therefore, if sucrose supply is low, it will cause a failure in filling the seeds (Egli and Bruening, 2005), so the number of empty pods increases.

On the other hand, the weight of 100 Seeds is a character to determine the size of soybean seeds. The greater the weight of 100 soybeans seeds, the bigger size of soybean seeds. Soybean that grows in a shaded environment will experience a decrease in photosynthetic activity in the generative phase so that photosynthates allocation to reproductive organs decreases (Kakiuchi \& Kobata 2004). This causes smaller seed size compare to open conditions. This is evidenced by the weight of 100 seeds of Dena- 1 and Dena-2 varieties.

Interval setting of fertilizing by using $150 \%$ of recommended dosage under shaded conditions results in better crop yield. This finding is contradictive with the study by Das (2015), where is $100 \%$ recommended dosage of fertilizer are comparatively higher than other fertility level on soybean in intercropping with Jatropha curcas. According to Mawarni (2011), the number of pods per plant can be influenced by the dose of fertilizer applied. The flowering and fruiting of plants are highly dependent on nutrient absorption, so that if absorbed nutrients increase then the number of filled pods formed is higher, and vice versa if the number of nutrients absorbed is less than the amount empty pods are increasing.

Idwar et al. (2014) states that pod formation phase requires sufficient $\mathrm{N}$ nutrients because the need for hormones and enzymes is quite large. To stimulate the formation of flowers, fruit and seeds and make seeds bigger, plants need $P$ element. Whereas to increase the translocation of sugar in the formation of starches and proteins (food reserves), plants need $\mathrm{K}$ element. The large number of pods formed will affect the soybean yield. The formation of soybean pods is strongly influenced by availability of nutrients, water and sunlight.

Related to the weight of seeds, proper fertilization as the needs and environmental conditions can provide optimal production. Nelvia et al. (2011) states that photosynthate excess as a result of photosynthesis process will be utilized for pods formation and then stored in seeds. In addition, the increased assimilation produced by plants will increase amino acids synthesis, proteins and organic compounds. These organic compounds are stored on the seeds, thereby increasing the weight and size of the seeds. 
However, productivity comparison of the varieties tested with the same varieties (Burangrang and Pangrango) grown under normal conditions, the weight of 100 soybeans shaded by Mindi stand were approximately 32\% and 43\% lower than the weight of 100 seeds with conventional cultivation of $20,53 \mathrm{gr}$ and $22.47 \mathrm{gr}$ (Bakhtiar et.al, 2014).

Number of pods will affect the yield of soybeans. Formation of soybean pods is strongly influenced by availability of nutrients, water and sunlight. Besides that, the responsiveness of varieties to fertilization also provides a significant role in influencing crop yields. Amali et.al (2015) explains that nutrients are needed for the growth of transplanted soybean in the form of dry matter during the growth phase then at the end of the vegetative phase there will be a accumulation of photosynthesis in plant organs such as stems, fruits and seeds.

These finding directly prove the potential for cultivation of shade-tolerant soybean development with an optimal fertilizer package. Some similar research finding also indicate the potential for shade-resistant soybeans, although with different varieties such as Anjasmoro (Jauhari et al., 2016), Ceneng (Jufri, 2006), Ceneng and Pangrango (Muhuria et.al, 2006; Mawarni, 2011), and Kipas Merah Bireuen (Chairuddin et.al, 2015).

Pod filling in this study are closely related to nutrient content and sunlight. Sufficient availability of nutrients and light intensity will support the formation of flowers in the generative phase. Irdiawan and Rahmi (2002) stated that the process of pod filling is needed maximum sunlight and sufficient water for some time.

The pod filling phase is strongly influenced by the elements of $N$ and $P$ in the soil. The higher nitrogen element will increase the photosynthesis process as a major factor in the formation of pods and seeds. Nitrogen deficiency causes imperfect growth of pods to mature quickly and has high protein content. The $P$ element also greatly affects soybean yield.

P-element deficiency causes late pods ripening and reduce soybean yield. The number of filled pods in shaded plants at responsive fertilizing doses ( 0.5 and 1.5 recommendations) is greater than unresponsive varieties, which is around 9-20 pods (figure 3), and the situation occurs because generative phase is sensitive phase to shade (Mathew et al. 2000). It can be seen that $\mathrm{N}, \mathrm{P}$ and $\mathrm{K}$ uptake in soybean monoculture cropping patterns is higher than in agroforestry patterns which causes the number of filled pods in monoculture higher than agroforestry patterns.

In shade-sensitive varieties, decrease in the number of filled pods is caused by inhibition of plant metabolic processes due to low light intensity. The low amount of light received by each leaf surface area causes a decrease in the rate of photosynthesis which can be seen from the reduced weight of dry mass and carbohydrate synthesis. This implies a decrease in the amount of photosynthate supply to the seeds so that there is a decrease in the number of filled pods. Decreased seed production due to shade on various plants was also reported by several researchers. Asadi et al. (1997) reported low light intensity reduce yield of soybean.

The decrease in dry seed weight is a result of a decrease in the number of filled pods. This is caused by the low light intensity received by plants due to shade which results in a decrease in photosynthetic activity of each variety so that the allocation of photosynthate to the reproductive organs is reduced.

Dena-1 variety with fertilizer 1.5 times of recommended dosage has the highest seed weight per plot compared to all treatment combinations, which is 464 grams/plot, while Dena2 at the 1.5 of recommended dose has the lowest seed weight per plot, followed by Burangrang with recommended dosages, namely $118.3 \mathrm{gr} / \mathrm{plot}$ and $139.4 \mathrm{gr} / \mathrm{plot}$, respectivelly. Sopandie et al. (2003) explained that the number of branches, total number of segments, number of filled pods, total number of pods, and percentage of filled pods was positively correlated and very significant to the weight of seeds per plant. The ability of soybeans tested in producing high seed weight per plant shows that soybeans are able to use sunlight efficiently for pods filling so that even in stress conditions it is still able to maintain high yields (Asadi et al. 1997). 


\section{CONCLUSION}

The conclusion that can be drawn in this study is the growth of soybean varieties in the mindi shade in the agroforestry system produces a different response. The difference in growth response is closely related to environmental conditions such as light intensity, temperature and humidity levels received so that it affects the plant height parameters, leaf chlorophyll, flowering age and yield components. In addition to shade, fertilization also has a significant effect, where under shaded conditions, to produce optimal growth, a dosage of $150 \%$ of the recommendations is required, with soybean Dena- 2 variety the most adaptive variety.

\section{REFERENCES}

1. Amali R, Nelvia S, Yoseva (2015). Respon tanaman kedelai (Glycine Max (L.) Merril) sebagai tanaman sela pada kebun kelapa sawit belum menghasilkan (tbm) dengan aplikasi pemupukan. JOM Faperta, 2(1) (in Indonesian).

2. Asadi B, Arsyad M, Zahara H, Darmijati (1997). Pemuliaan kedelai untuk toleran naungan and tumpangsari. Bul. Agrobio 1 (2):1520 (in Indonesian).

3. Bakhtiar, Hidayat T, Jufri Y, Safriati S (2014). Keragaan pertumbuhan and komponen hasil beberapa varietas unggul kedelai di aceh besar. J. Floratek 9: 46 - 52 (in Indonesian).

4. Begonia GB, Aldrich RJ, Nelson CJ (1988). Effects of simulated weed shade on soybean photosynthesis, biomass partitioning and axillary bud development. Photosynthetica 22:309-319.

5. Board J E (2013). Preface in a comprehensive survey of international soybean research genetics, physiology, agronomy and nitrogen relationships. In-Tech. Rijeka, Croatia.

6. Burkey KO, Wilson RF, Wells R (1997). Effects of canopy shade on the lipid composition of soybean leaves. Physiol Plant 101:591-598. doi:10.1111/j.1399-3054.1997.tb01042.x.

7. Caron BO, Sgarbossa J, Schwerz F, Elli EF, Eloy E, Behling A (2018). Dynamics of solar radiation and soybean yield in agroforestry systems. Annals of the Brazilian Academy of Sciences. 90(4): 3799-3812. http://dx.doi.org/10.1590/0001-3765201820180282

8. Chairuddin, Efendi, Sabaruddin (2015). Dampak naungan terhadap perubahan karakter agronomi and morfo-fisiologi daun pada tanaman kedelai (Glycine max (L.) Merrill). J. Floratek 10: 26 - 35 (in Indonesian).

9. Croce R, Muller MG, Bassi R, Holzwarth AR (2001). Carotenoid to chlorophyll energy transfer in ecombinant major light harvesting cmplex (LHCII) of higher plants. I. Femtosecond transient absorption measurements. Biophys J. 80:901915.

10. Das N (2015). Comparative growth analysis and yield performance of glycine max under jatropha curcas based agrisilviculture system of agroforestry in the northern part of Bangladesh. Journal of Forests 2(2):14-23. DOI: 10.18488/journal.101/2015.2.2/101.2.14.23.

11. Djukri, Purwoko BS (2003). Pengaruh naungan paranet terhadap sifat toleransi tanaman talas (Colocasia esculenta (L.) Schott). Ilmu Pertanian. 10(2): 1725 (in Indonesian).

12. Egli DB, Bruening WP (2001). Source-sink relationships: seed sucrose levels and seed growth rates in soybean. Annals of Botany 88:235-242. https://doi.org/10.1006/anbo.2001.1449.

13. Egli DB, Leggett JE, Cheniae A (1980) Carbohydrates levels in soybean leaves during reproductive growth. Crop Sci 20:468-473

14. Handayani T (2003). Pola pewarisan sifat toleran terhadap intensitas cahaya rendah pada kedelai (Glycine max L. Merr) dengan penciri spesifik karakter anatomi, morfologi and molekuler [disertasi]. Bogor (ID): Institut Pertanian Bogor (in Indonesian).

15. Hartoyo APP (2014). Pertumbuhan and produksi kedelai (Glycine max L. Merr) berbasiskan agroforestry sengon (Paraserianthes falcataria (L.) Nielsen. [Thesis]. Bogor (ID): Institut Pertanian Bogor (in Indonesian). 
16. Heindl JC, Brun WA (1983) Light and shade effects on abscission and 14Cphotoassimilate partitioning among reproductive structures in soybean. Plant Physiol 73:434-439.

17. Idwar, Nelvia, Arianci R (2014). Pengaruh campuran kompos tandan kosong kelapa sawit, abu boiler and trichodermaterhadap pertanaman kedelai pada sela tegakan kelapa sawit yang telah menghasilkan di lahan gambut. Jurnal Teknobiologi, 1: $21-29$ (in Indonesian).

18. Irdiawan R, Rahmi A (2002). Pengaruh jarak tanam and pemberian bokhasi pupuk kandang ayam terhadap pertumbuhan and hasil kacang tanah (Arachis hypogea $\mathrm{L}$ ). $\mathrm{J}$ Agrifor. 1(2):31-36 (in Indonesian).

19. Jauhari AM, Wijayanto N, Rusdiana O (2016). Pertumbuhan mindi (Melia azedarach Linn.) and produksi kedelai (Glycine max (L.) Merril) dengan pola agroforestri pada lahan masam. Jurnal Silvikultur Tropika 7(3): 198-204 (in Indonesian).

20. Jufri A (2006). Mekanisme adaptasi kedelai (Glycine max (L.) Merrill) terhadap cekaman intensitas cahaya rendah. [disertasi]. Bogor (ID): Institut Pertanian Bogor (in Indonesian).

21. Kakiuchi J, Kobata T (2004). Shading and thinning effects on seed and shoot dry matter increase in determinate soybean during the seed-fi lling period. Agron J. (96):398-405.

22. Karamoy LT (2009). Hubungan iklim dengan pertumbuhan kedelai (Glycine max L Merrill). Soil Environment 7:65-68.

23. Kisman, Khumaida N, Trikoesoemaningtyas, Sobir, Sopandie D (2007). Karakter morfofisiologi daun, penciri adaptasi kedelai terhadap intensitas cahaya rendah. Bul. Agron. 35:96-102 (in Indonesian).

24. Manceur AM, Boland GJ, Thevathasan NV, Gordon AM (2008). Dry matter partitions and specific leaf weight of soybean change with tree competition in an intercropping system. Agroforest Syst (2009) 76:295-301. DOI 10.1007/s10457-008-9181-y.

25. Matsuo N, Koichiro F, Tsuchiya S (2016). Effects of early planting and cultivars on the yield and agronomic traits of soybeans grown in southwestern Japan. Plant Prod Sci 19: 370-380.

26. Mathew JP, Herbert SJ, Zhang S, Rautenkranz AAF, Litchfi GV (2000). Different response of soybean yield component to the timing of light enrichment. Agron $\mathrm{J}$. 92:1156-1161.

27. Mawarni $L$ (2011). Kajian awal varietas kedelai tahan naungan untuk tanaman sela pada perkebunan kelapa sawit. Jurnal IImu Pertanian, 5(2):54-59 (in Indonesian).

28. Muhuria, Tyas KN, Khumaida N, Trikoesoemaningtyas, Sopandie D (2006). Adaptasi tanaman kedelai terhadap intensitas cahaya rendah: Karakter daun untuk efisiensi penangkapan cahaya. Bul. Agron. 34(3):133-140 (in Indonesian).

29. Nelvia, Yetti H, Indrawadi L (2011). Pengaruh pemberian molibdenum (Mo) terhadap pertumbuhan and produksi kedelai. Jurnal Teknobiologi, 2(1): 91-95 (in Indonesian).

30. Peet MM, Kramer PJ (1980). Effect of decreasing source/sink ratio in soybeans on photosynthesis, photorespiration, transpiration and yield. Plant Cell Environ 3:201-206.

31. Qadir A (2012). Pemodelan pertumbuhan tanaman kedelai (Glycine max L. Merr) di bawah cekaman naungan. [disertasi]. Bogor (ID): Institut Pertanian Bogor (in Indonesian).

32. Querné A, Battie-laclau P, Dufour L, Wery J, Dupraz C (2017). Effects of walnut trees on biological nitrogen fixation and yield of intercropped alfalfa in a Mediterranean agroforestry system. Europ. J. Agronomy 84 (2017) 35-46. http://dx.doi.org/10.1016/j.eja.2016.12.001.

33. Reynolds PE, Simpson JA, Thevathasan NV, Gordon AM (2007). Effects of tree competition on corn and soybean photosynthesis, growth, and yield in a temperate treebased agroforestry intercropping system in southern Ontario, Canada. Ecol. Eng. 29, 362-371.

34. Richards RA (2000). Selectable traits to increase crop photosynthesis and yield of grain crops. J.Exp.Bot. 51:447-458. https://doi.org/10.1093/jexbot/51.suppl_1.447. 
35. Salton JC, Mercante FM, Tomazi M, Zanatta JA, Concenço G, Silva WM, Retorea M (2013). Integrated crop-livestock system in tropical Brazil: toward a sustainable production system. Agric Ecosyst Environ 190: 70-79.

36. Sopandie D, Marzuki I, Jusuf M (2003). Alumunium tolerance in soybean: protein profiles and accumulation of in roots. Hayati 10 (1):30-33.

37. Tracy BF, Zhang Y (2008). Soil compaction, corn yield response, and soil nutrient pool dynamics within an integrated crop-livestock system in Illinois. Crop Sci 48(3): 12111218.

38. Trang KM, Giddens J (1980). Shading and temperature as environmental factors affecting growth, nodulation, and symbiotic N2 fixation by soybeans. Agron J 72:305308.

39. Vishwanath BR, Nagarjaiah C, Raghavendra SM, Jayashree MK (2014). Evaluation of Soybean Yield under Biofuel Based Agroforestry System. Environment \& Ecology 32 (3A): 1194-1199.

40. Wahua TAT, Miller DA (1978). Effects of shading on the N2-fixation, yield, and plant composition of field-grown soybeans. Agron J 70:387-392.

41. Wijayanto N, Dewi N, Wardani A (2016). Growth response of soybean (Glycine max (I.) Merrill) to addition sentang leaves (Azadirachta excelsa (jack.) Jacobs) and mindi leaves (Melia Azedarach Linn.). Jurnal Silvikultur Tropika 7(3):39-41.

42. Wirnas D (2007). Pemilihan karakter seleksi berdasarkan analisis biometric and molekuler untuk merakit kedelai toleran intensitas cahaya rendah. [disertasi]. Bogor (ID): Institut Pertanian Bogor (in Indonesian). 